\title{
2011 Bunsen-Kirchhoff Award for Analytical Spectroscopy
}

\section{DASp Deutscher Arbeitskreis für angewandte Spektroskopie}

\section{Detlef Günther}

(C) Springer-Verlag 2010

The German Working group for Applied Spectroscopy (DASp) regularly awards the "Bunsen-Kirchhoff-Preis für analytische Spektroskopie" to honour preferably the work of young scientists from universities, research institutes or industry who made excellent contributions to analytical spectroscopy. Especially preferred is an oeuvre in new areas like spectroscopy in nano compartments, spectroscopy of biomolecules etc. DASp is now seeking nominations for the 2011 BunsenKirchhoff Award for Analytical Spectroscopy. The winner of the Award will receive a certificate and $€ 2.500$ sponsored by Perkin Elmer GmbH. The Award will be presented at the Anakon in March 2011 in Zürich (Switzerland).

Nominations can be made by members of DASp but eligibility is open for any scientist meeting the requirements. Self-nomination is excluded. The winner will be decided by a jury consisting of the current members of the board of DASp.
Further information is available at: http:/www.gdch.de/ strukturen/fg/ach/aks/dasp.htm

A nomination should include:

1. A letter with the candidate's accomplishments,

2. A list of publications or recent work,

3. A scientific curriculum vitae stating the age of the candidate; the candidate's address, phone fax and e-mail.

All documents should be sent not later than 31 December 2010 to:

Prof. Dr. Detlef Günther,

Chair of the Jury for the Bunsen-Kirchhoff Award 2011, Laboratorium für Anorganische Chemie, ETH Hönggerberg, HCI, CH-8093 Zürich (Schweiz)

(detlef.guenther@inorg.chem.ethz.ch)

D. Günther $(\bowtie)$

Chair of the Jury for the Bunsen-Kirchhoff Award 2011,

Laboratorium für Anorganische Chemie, ETH Hönggerberg, HCI,

CH-8093 Zürich, Switzerland

e-mail: detlef.guenther@inorg.chem.ethz.ch 